\title{
Reproductive success of planktivorous seabirds in the North Pacific is related to ocean climate on decadal scales
}

\author{
Alexander L. Bond ${ }^{1, *}$, Ian L. Jones ${ }^{1}$, William J. Sydeman ${ }^{2}$, Heather L. Major ${ }^{1,5}$, \\ Shoshiro Minobe ${ }^{3}$, Jeffrey C. Williams ${ }^{4}$, G. Vernon Byrd ${ }^{4}$ \\ ${ }^{1}$ Department of Biology, Memorial University of Newfoundland, St. John's, Newfoundland and Labrador A1B 3X9, Canada \\ ${ }^{2}$ Farallon Institute for Advanced Ecosystem Research, PO Box 750756, Petaluma, California 94975, USA \\ ${ }^{3}$ Graduate School of Sciences, Hokkaido University, N10 W8, Sapporo 060-0810, Japan \\ ${ }^{4}$ Alaska Maritime National Wildlife Refuge, United States Fish and Wildlife Service, 95 Sterling Highway, Suite 1, Homer, \\ Alaska 99603, USA
}

${ }^{5}$ Present address: Centre for Wildlife Ecology, Department of Biological Sciences, Simon Fraser University, 8888 University Drive, Burnaby, British Columbia V5N 1S6, Canada

\begin{abstract}
Growing evidence indicates relationships between seabird demography and both largeand small-scale variation in climate and oceanography, yet few studies have examined multiple species and locations simultaneously. As secondary consumers, least, whiskered, and crested auklets (Aethia pusilla, A. pygmaea, and A. cristatella, respectively), congeneric planktivorous seabirds endemic to the Bering and Okhotsk seas, are expected to respond to changes in ocean climate due to their low trophic positioning. From 1990 to 2008, we measured reproductive success (productivity) and breeding phenology (mean hatching date) of auklets on Buldir, Kiska, and Kasatochi, 3 islands spanning $585 \mathrm{~km}$ across the Aleutian Islands, Alaska, USA. A model including Island, Species, and Winter Aleutian Low Pressure Index (ALPI) best explained productivity, with reproductive success decreasing among all species with increasing ALPI $(\beta=-0.273 \pm 0.0263$ [SE]), likely through control of water temperature and prey (zooplankton) availability. Auklet productivity also increased with increasing winter sea surface temperature (SST) in the western North Pacific and western Bering Sea (and correspondingly decreased with increasing SST in the Gulf of Alaska), and was correlated negatively with spring sea-level air pressure in the North Pacific. These responses are reflective of positive values of the Aleutian low pressure system. Though our datasets cover only $19 \mathrm{yr}$ or less, we found similar correlations between climate and auklet productivity among all species and islands. Together, our results suggest that ocean climatic conditions and reproductive success of planktivorous auklets are significantly related.
\end{abstract}

KEY WORDS: Productivity · Oceanography · Demography · Aethia spp. $\cdot$ Least auklet $\cdot$ Crested auklet $\cdot$ Whiskered auklet $\cdot$ Aleutian Islands

\section{INTRODUCTION}

Climate and oceanographic conditions in the North Pacific Ocean covary on decadal time scales or longer (Overland et al. 1999, Biondi et al. 2001), often characterized by 'regimes' of 20 to $30 \mathrm{yr}$ duration (Hare \&
Mantua 2000, Biondi et al. 2001, d'Orgeville \& Peltier 2009). A well known regime shift occurred in 19761977, with warmer sea surface temperature (SST), lower sea-level pressure (SLP), and a more intense Aleutian low pressure system (Aleutian low) (Hare \& Mantua 2000, Rodionov et al. 2005). In the North 
Pacific and Bering Sea, this shift resulted in greater climatic variability (Bond et al. 2003, Hunt \& Elliott 2004, Rodionov et al. 2005), greater stratification of the water column, and increased primary productivity (Trenberth \& Hurrell 1994, Iida \& Saitoh 2007). Other purported ecosystem shifts have occurred in 1989-1990 and 1998-1999, but these putative shifts in system state have not been well documented (Overland et al. 1999, Hare \& Mantua 2000, Mueter et al. 2007).

Seabirds, as conspicuous, generally unexploited, secondary and tertiary consumers in marine systems, provide a unique opportunity to investigate coupled climate-ecosystem variation (Durant et al. 2009). Indeed, the relationship between ocean climate, ranging from direct measures of SST to multivariate climate indices, e.g. Pacific Decadal Oscillation (PDO) (Mantua \& Hare 2002), and seabird breeding performance has been investigated frequently in the North Pacific (e.g. Gjerdrum et al. 2003, Abraham \& Sydeman 2004, Byrd et al. 2008) and elsewhere (e.g. Harris et al. 2005, Durant et al. 2006, Møller et al. 2006, Lavers et al. 2008, Jenouvrier et al. 2009). Some authors found significant relationships between large-scale climate indices and seabird demographic rates (Kitaysky \& Golubova 2000, Byrd et al. 2008, Sandvik et al. 2008), whilst others did not (Wanless et al. 2009). In the North Pacific, variation in seabird breeding performance is thought to result from 'bottom-up' climate forcing of seabird prey abundance (Lehodey 2004).

While linkage between climatic and oceanographic variability has been found in many marine organisms (Beamish et al. 1997, Mantua et al. 1997, Chavez et al. 1999, Hunt et al. 2002, 2008, Durant et al. 2006, Byrd et al. 2008), most studies did not address spatial components in climatic and oceanographic variability. Integrating data over large areas can mask smaller-scale variation over space and time. More recently, there has been a focus on examining relationships between seabirds' demography and oceanographic variables in spatial terms, providing a better understanding of how geographic patterns of climate affect marine species (Byrd et al. 2008, Watanuki et al. 2009).

Auklets (Charadriiformes: Alcidae: Aethia) are a group of planktivorous seabirds occurring in the Bering and Okhotsk Seas. They consume and provision offspring with zooplankton, primarily euphausiid crustaceans and large copepods (Day \& Byrd 1989, Flint \& Golovkin 2002, Gall et al. 2006). Annual reproductive output is reflected by success in the hatching and rearing of offspring from a single egg (Byrd \& Williams 1993, Jones 1993a,b). Here, we test the hypothesis that the productivity (and timing of breeding) of auklets covaries with ocean climate, and that this covariation is consistent among species and breeding colonies in the western Aleutian Islands. We con- sidered the correlation between productivity, largescale ocean climate indices (Aleutian Low Pressure Index [ALPI], PDO), and direct measures of SST and SLP based on satellite data for 3 auklet species: least, whiskered, and crested auklets (Aethia pusilla, A. pygmaea, and A. cristatella) breeding on Buldir, Kiska, and Kasatochi in the central and western Aleutian Islands, Alaska (Fig. 1). Our objectives were to: (1) quantify relationships between auklet reproductive success and indices and direct measures of ocean climate; (2) identify the oceanographic regions where productivity-climate correlations are strongest; (3) examine the covariance in productivity among different island-breeding colonies and among different auklet species; and (4) to better understand underlying mechanisms determining demographic variation in planktivorous seabird species in the North Pacific.

\section{MATERIALS AND METHODS}

Productivity (the proportion of eggs laid that produced independent young) and phenology (mean date of hatching of eggs) were measured over 19 yr (1990$2008)$ at Main Talus, Buldir $\left(52^{\circ} 22.45^{\prime} \mathrm{N}, 175^{\circ} 54.33^{\prime} \mathrm{E}\right.$; least and crested auklets, 1990-2008; whiskered auklets, 1991-2008), Thundering Talus, Kasatochi $\left(52^{\circ} 10.77^{\prime} \mathrm{N}, 175^{\circ} 31.48^{\prime} \mathrm{W}\right.$; least and crested auklets, 1996-2008), and at Sirius Point, Kiska (52 08' N, $177^{\circ} 36^{\prime} \mathrm{E}_{\text {; least }}$ and crested auklets, 2001-2008), in the Aleutian Islands, Alaska. No data were collected from Buldir in 1999 or from Kiska in 2005 due to logistical constraints.

Auklet productivity. Each year, we checked a sample of auklet breeding nest sites (rock crevices) from late May until early August using established protocols (for details see Fraser et al. 1999, Hunter et al. 2002, Major et al. 2006), encompassing the entire breeding season for all 3 species. To account for potential vari-

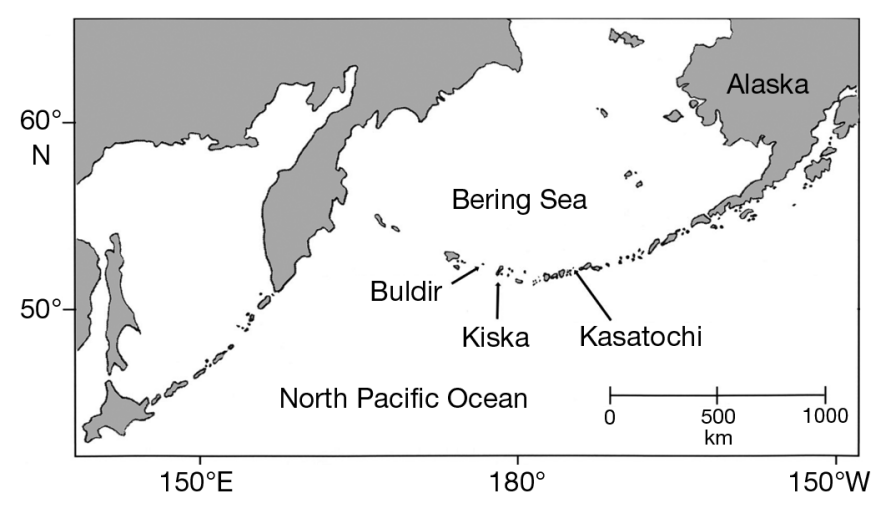

Fig. 1. North Pacific Ocean with productivity measurement study sites on the islands Buldir, Kiska, and Kasatochi, Aleutian Islands, Alaska, indicated 
ability among islands, years, and observers, one trained observer was stationed on each island in each year to ensure consistency. Within each year, the same individual would check the same nest sites, and all observers used the same methods and criteria for determining nest success (Fraser et al. 1999, Major et al. 2006). We visited breeding sites every 4 to $7 \mathrm{~d}$ and determined their status (empty, egg, chick, adult, unknown). New sites were located and included in the sample each year, to account for previously monitored sites that were no longer in use, but the majority of crevice nests in most years consisted of sites that had been monitored in previous years. We assumed that our annual sample of breeding sites monitored at each colony was representative and reflective of productivity at each colony site. We considered sites active when we found an adult on 2 consecutive visits, or when we saw an egg. We scored sites as successful in fledging a chick if the chick disappeared after $25 \mathrm{~d}$ for least auklets (Roby \& Brink 1986a), 26 d for crested auklets (Fraser et al. 1999) or $32 \mathrm{~d}$ for whiskered auklets (Hunter et al. 2002).

Timing of breeding. We estimated date of hatching for a sub-sample of crevice breeding sites monitored. We included only crevices that we scored as an egg on one visit, and as a chick on the very next visit (4 to $7 \mathrm{~d}$ later), and we assumed hatching date to have occurred at the midpoint between the 2 visits. We then used the mean hatching date for each species-island combination in each year as a measure of timing of breeding.

Climate and oceanographic data. We used multiple large-scale atmospheric and oceanographic climate indices, and evaluated their relationship to auklet reproductive success. While metrics of climate are interrelated, as might be expected, we chose a variety of indicators since no one index reflects the variability of the North Pacific adequately (Bond et al. 2003). The ALPI (Beamish \& Bouillon 1993, Beamish et al. 1997) is the anomaly from the 1950 to 1997 mean of the area with pressure $\leq 100.5 \mathrm{kPa}$ over the area 20 to $70^{\circ} \mathrm{N}$, $120^{\circ} \mathrm{E}$ to $120^{\circ} \mathrm{W}$; positive ALPI values indicate a relatively strong Aleutian low-pressure system. ALPI is centered on our study area (approximately 51 to $53^{\circ} \mathrm{N}$, $175^{\circ} \mathrm{E}$ to $175^{\circ} \mathrm{W}$ ). The related North Pacific Index (NPI) is the area-weighted sea-level pressure over the region bounded by 30 to $65^{\circ} \mathrm{N}$ and $160^{\circ} \mathrm{E}$ to $140^{\circ} \mathrm{W}$ (Trenberth \& Hurrell 1994). The PDO is a temporally long (20 to 30 yr) El Niño Southern Oscillation (ENSO)like oscillation based on the leading principle component of SST north of $20^{\circ} \mathrm{N}$ (Mantua et al. 1997). Finally, the North Pacific Gyre Oscillation (NPGO) is derived output from a model; it represents the second principal component of sea surface height anomalies measured over the same areas as the PDO (Di Lorenzo et al. 2008). Several of these indices (ALPI, NPI, and PDO) have been related to auklet demography (Jones et al. 2002)

For SST, we used the $4 \mathrm{~km}$ AVHRR (advanced very high resolution radiometer) Pathfinder Version 5 dataset (available at www.nodc.noaa.gov/SatelliteData/ pathfinder4km/available.html). We measured SST in a $50 \mathrm{~km}^{2}$ radius around each colony, reflecting the likely foraging range of auklets (Obst et al. 1995, Thayer et al. 2008, Wolf et al. 2009). We assessed SST during June and July, when auklets are present at the breeding colonies. For our geospatial approach (see 'Statistical procedures' below), large-scale climate data (SST and SLP) over the North Pacific were taken from the National Centers for Environmental Protection/ National Center for Atmospheric Research (NCEPNCAR) reanalysis (Kalnay et al. 1996).

Statistical procedures. All statistical tests were performed in SPSS 16.0.2, and were weighted by the sample size of nest sites studied each year for each species at each island. To investigate whether there were linear trends in productivity or timing of breeding over time, we used a linear regression for each speciesisland combination. We used nonparametric correlations (Spearman's $\rho$ ) to look for covariance among and between species and islands (Byrd et al. 2008). To control for multiple comparison error inflation, we used the False Discovery Rate (Benjamini \& Hochberg 1995), which is less restrictive and more powerful than a Bonferroni-type family-wise correction (García 2004, Grosbois et al. 2008). We use $\mathrm{p}<0.10$ to determine significance. Setting a higher $\alpha$ level is desired when the sample size (in this case, number of years) is low, to increase the power to detect a relationship when one is present (Lebreton et al. 1992, Field et al. 2004, Grosbois et al. 2008). This approach has been used regularly in other studies of seabirds in the North Pacific (e.g. Abraham \& Sydeman 2004, Byrd et al. 2008).

We used a 3-step process to investigate relationships among ocean climate and auklet productivity. First, we used Spearman rank correlations to search for potential parameters to include in a statistical model. Second, as this analysis does not account for spatial variability in variables (e.g. SST and SLP), we examined spatial correlations to provide inference regarding spatial variability (Szép \& Møller 2005, Schroeder et al. 2009, Watanuki et al. 2009); we limited this analysis to the Buldir and Kasatochi time series, which were $>10 \mathrm{yr}$ in duration. Spearman correlation coefficients between reproductive success and SLP or SST were mapped over the North Pacific and Bering Sea, and areas of significant correlations $(p<0.10)$ were delineated. We used generalized linear models with a binomial logit-link function (a logistic regression approach), to select the most important climate variables. Variable selection was based upon quasi- 
Akaike's Information Criteria adjusted for small sample sizes $\left(\mathrm{QAIC}_{\mathrm{c}}\right)$ and extra-binomial variation by including an estimate of model deviance $(\hat{\mathrm{c}}=$ model deviance $\div$ df for the global model). We chose this information-theoretic approach rather than a nullhypothesis testing because the variation in the dependent variable (productivity) was generally small (9 to $16 \%$ among all species and all islands) (Grosbois et al. 2008). We considered the model with the lowest QAIC $_{c}$ value to be the best-fitting model for the data (Burnham \& Anderson 2002). We constructed 12 a priori models composed of biologically plausible combinations of 5 variables of interest, including a Null Model (intercept only) and a Global Model that included all additive terms, and their interactions with species and islands. Once the best-fitting model was identified, the climate and oceanographic covariates of interest and biologically important interaction terms were added to subsequent models to examine the effect of climate, a similar procedure to the modeling of recapture rate and then survival rate in mark-recapture studies (Lebreton et al. 1992, Grosbois et al. 2008). We only included potential climate covariates that were correlated significantly with auklet reproductive performance in our preliminary assessment. This decreases the number of candidate models and reduces the risk of multi-collinearity in covariates (Grosbois et al. 2008). Models with QAIC $_{c}>2$ were considered to have substantially less support, and overall model support was assessed using Akaike weights $\left(\mathrm{w}_{i}\right)$ (Burnham \& Anderson 2002). This was done on both the full dataset and again using data from Buldir and Kasatochi only, as in the geospatial analysis. In the latter case, Kiska is excluded because its observation period was shorter (7 yr), and because Kiska is anomalous in that it also has introduced predators that affect auklet reproductive performance. Finally, we used the estimated marginal means (EMMs) from the topranked generalized linear model to examine differences among species and islands, and differences were considered significant if $95 \%$ confidence intervals did not overlap.

\section{RESULTS}

We studied between 23 and 215 breeding pairs of each species on each island in each year $($ total $=7733$ breed- ing sites over all years and all species) (Table S1 in the supplement at www.int-res.com/articles/suppl/ m424p205_supp.pdf). Auklet productivity ranged from 0.10 to 0.85 chicks per nest for most species for most years, with 2001 and 2002 being unusually low on Kiska, and 2003 being unusually low on Buldir (Fig. 2; Table S2 in the supplement at www.int-res.com/ articles/suppl/m424p205_supp.pdf).

Linear regression identified only one significant trend in reproductive success or phenology. Since that trend was an increase in reproductive success over time for least auklets on Kiska, our smallest dataset $(p=0.012$, all other sites $p>0.11)$, we used raw data, not detrended values, for further comparisons (Tables S2 \& S3 in the supplement at www.intres.com/articles/suppl/m424p205_supp.pdf). There was a general pattern of correlation among species within islands, and using our shortest time series (Kiska), 9 of 10 correlations were positive despite the small sample size $(\mathrm{n}=7 \mathrm{yr})$, providing reasonably strong evidence of covariation (Table 1). Timing of breeding was rarely correlated among species or islands; crested auklet timing of breeding on Buldir and Kiska was correlated positively (Table 2).

Productivity was related to ocean climate indices significantly in 2 cases. Of the relationships examined,

Table 1. Spearman's $\rho$ correlation matrix for breeding phenology (mean hatch date) of least (LEAU), crested (CRAU), and whiskered auklets (WHAU) on Buldir, Kiska, and Kasatochi in the Aleutian Islands from 1990 to 2008. Significant correlations after correcting for False Discovery Rate (see 'Statistical procedures') are indicated with *

\begin{tabular}{|lrrrrrr|}
\hline & $\begin{array}{r}\text { Buldir } \\
\text { LEAU }\end{array}$ & $\begin{array}{r}\text { Kiska } \\
\text { LEAU }\end{array}$ & $\begin{array}{c}\text { Kasatochi } \\
\text { LEAU }\end{array}$ & $\begin{array}{l}\text { Buldir } \\
\text { CRAU }\end{array}$ & $\begin{array}{c}\text { Kiska } \\
\text { CRAU }\end{array}$ & $\begin{array}{c}\text { Kasatochi } \\
\text { CRAU }\end{array}$ \\
\hline Kiska LEAU & -0.239 & & & & & \\
Kasatochi LEAU & 0.458 & -0.373 & & & & \\
Buldir CRAU & 0.581 & -0.108 & 0.378 & & & \\
Kiska CRAU & 0.667 & 0.200 & 0.616 & $0.900^{*}$ & & \\
Kasatochi CRAU & 0.388 & -0.248 & 0.519 & 0.208 & 0.051 & \\
Buldir WHAU & 0.452 & 0.673 & -0.196 & 0.445 & 0.821 & 0.092 \\
\hline
\end{tabular}

Table 2. Spearman's $\rho$ correlation matrix for productivity of least (LEAU), crested (CRAU), and whiskered auklets (WHAU) on Buldir, Kiska, and Kasatochi in the Aleutian Islands from 1990 to 2008. Significant correlations after correcting for False Discovery Rate (see 'Statistical procedures') are indicated with *

\begin{tabular}{|lrlrlll|}
\hline & $\begin{array}{r}\text { Buldir } \\
\text { LEAU }\end{array}$ & $\begin{array}{r}\text { Kiska } \\
\text { LEAU }\end{array}$ & $\begin{array}{c}\text { Kasatochi } \\
\text { LEAU }\end{array}$ & $\begin{array}{c}\text { Buldir } \\
\text { CRAU }\end{array}$ & $\begin{array}{c}\text { Kiska } \\
\text { CRAU }\end{array}$ & $\begin{array}{c}\text { Kasatochi } \\
\text { CRAU }\end{array}$ \\
\hline Kiska LEAU & 0.206 & & & & & \\
Kasatochi LEAU & -0.260 & 0.216 & & & & \\
Buldir CRAU & 0.569 & 0.090 & -0.249 & & & \\
Kiska CRAU & 0.581 & 0.643 & -0.601 & 0.219 & & \\
Kasatochi CRAU & 0.162 & $0.865^{*}$ & 0.373 & 0.127 & 0.543 & \\
Buldir WHAU & 0.375 & 0.793 & 0.018 & 0.469 & 0.402 & 0.565 \\
\hline
\end{tabular}




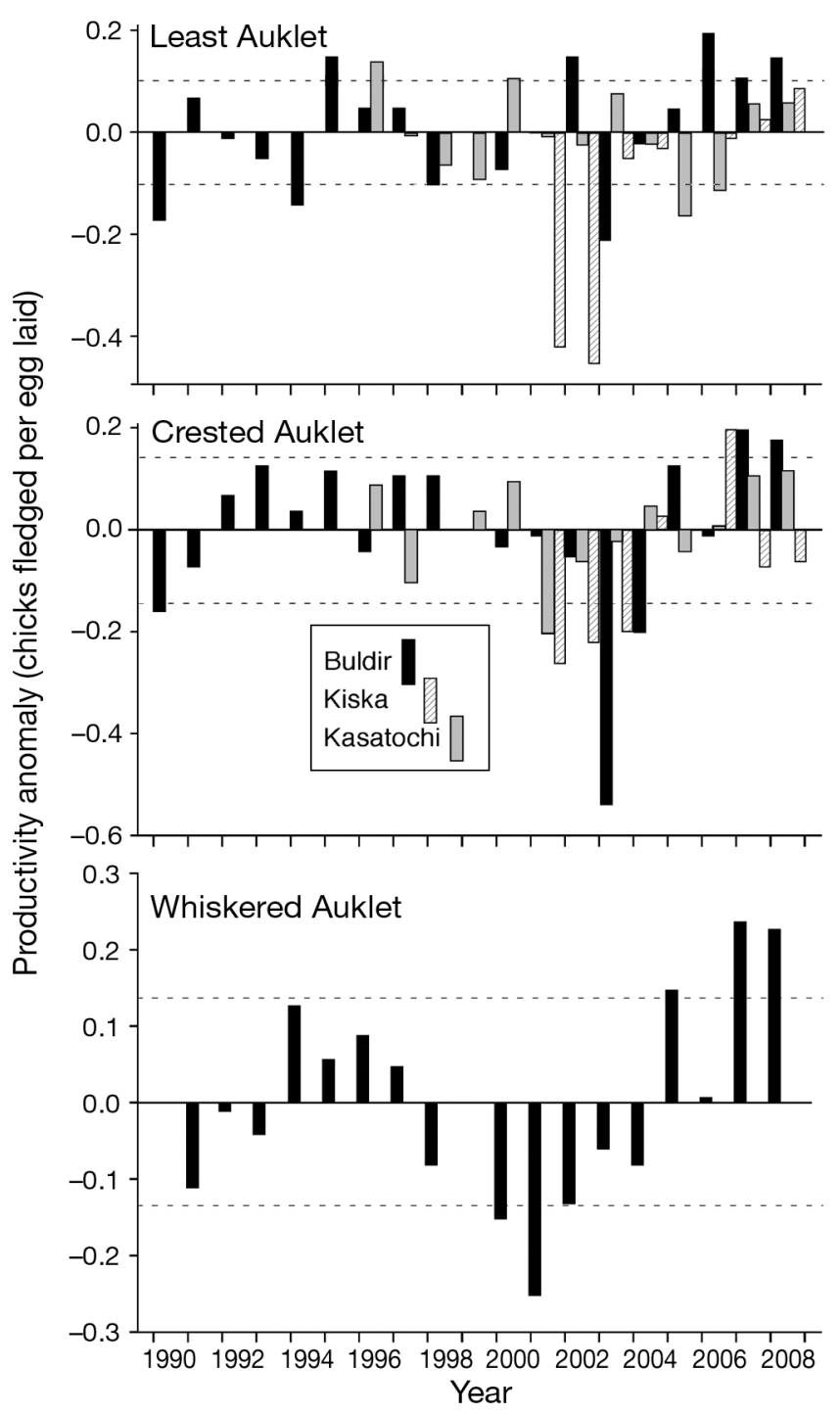

Fig. 2. Aethia pusilla, Aethia pygmaea, and Aethia cristatella. Productivity anomalies (differences from the overall mean) of least, crested and whiskered auklets on Buldir, Kiska and Kasatochi, Aleutian Islands, Alaska, from 1990 to 2008. Dashed lines indicate \pm 1 SD from the mean crested auklet productivity was related to the NPGO (Table 3). Of the climate covariates we considered, ALPI and the winter and spring NPGO were most often related to auklet productivity.

\section{Geospatial mapping of climate and reproductive success correlations}

In 4 cases, geospatial correlation analysis found that reproductive success was correlated with winter (December to February) SST (Fig. 3) but in different areas of the North Pacific. Productivity of least and crested auklets on Buldir was negatively correlated with SST in the Gulf of Alaska region, while that of whiskered auklets on Buldir was positively related to SST in the western Bering Sea. The spatial correlation pattern for least auklets on Buldir is characterized by a negative correlation along the American west coast and a positive correlation in the central North Pacific, reminiscent of the SST pattern of a negative PDO (Mantua et al. 1997). Reproductive success of crested auklets on Kasatochi was positively related to SST in the northwestern Pacific Ocean between 40 and $50^{\circ} \mathrm{N}$ (Fig. 3). The only relationship between reproductive success and spring (March to May) SST was for whiskered auklets breeding on Buldir, and the pattern was identical to that for winter SST. This pattern is similar to the second mode of SST variations (Bond et al. 2003), which is closely related to the NPGO (Di Lorenzo et al. 2009). This is consistent with the relatively high correlation between productivity and climate indices (Table 3). No significant relationships were found between reproductive success and winter SLP, and only 2 for spring SLP. Whiskered auklet reproductive success on Buldir was negatively related to SLP in the eastern Pacific, while that of least auklets on Kasatochi was negatively related to the spring SLP in the western Pacific (Fig. 4).

Table 3. Spearman's $\rho$ correlations for productivity and climate indices for least (LEAU), crested (CRAU), and whiskered auklets (WHAU) on Buldir, Kiska, and Kasatochi in the Aleutian Islands from 1990 to 2008. ${ }^{*}$ : Significant correlations after correcting for False Discovery Rate (see 'Statistical procedures'). ALPI: Aleutian Low Pressure Index, NPGO: North Pacific Gyre Oscillation, PDO: Pacific Decadal Oscillation, SST: sea surface temperature

\begin{tabular}{|c|c|c|c|c|c|c|c|c|}
\hline & ALPI & $\begin{array}{c}\text { NPGO } \\
\text { Dec-Feb }\end{array}$ & $\begin{array}{c}\text { NPGO } \\
\text { Mar-May }\end{array}$ & $\begin{array}{c}\text { NPI } \\
\text { Dec-Mar }\end{array}$ & $\begin{array}{c}\text { NPI } \\
\text { Aug-Apr }\end{array}$ & $\begin{array}{c}\text { PDO } \\
\text { Dec-Mar }\end{array}$ & $\begin{array}{c}\text { PDO } \\
\text { Aug-Apr }\end{array}$ & SST \\
\hline Buldir LEAU & -0.161 & -0.127 & -0.148 & 0.258 & 0.350 & -0.532 & -0.411 & -0.436 \\
\hline Kiska LEAU & -0.707 & -0.729 & -0.528 & 0.021 & 0.029 & 0.281 & 0.054 & 0.406 \\
\hline Kasatochi LEAU & -0.103 & 0.283 & 0.271 & -0.133 & -0.278 & -0.128 & -0.142 & 0.368 \\
\hline Buldir CRAU & -0.313 & -0.387 & -0.297 & 0.227 & 0.264 & -0.192 & -0.295 & -0.027 \\
\hline Kiska CRAU & -0.469 & $-0.945^{*}$ & $-0.835^{*}$ & 0.287 & 0.436 & 0.029 & -0.086 & 0.091 \\
\hline Kasatochi CRAU & -0.373 & -0.169 & -0.038 & 0.191 & 0.128 & -0.122 & -0.324 & 0.198 \\
\hline Buldir WHAU & -0.529 & -0.474 & -0.415 & 0.307 & 0.231 & 0.114 & 0.033 & 0.053 \\
\hline
\end{tabular}


Buldir
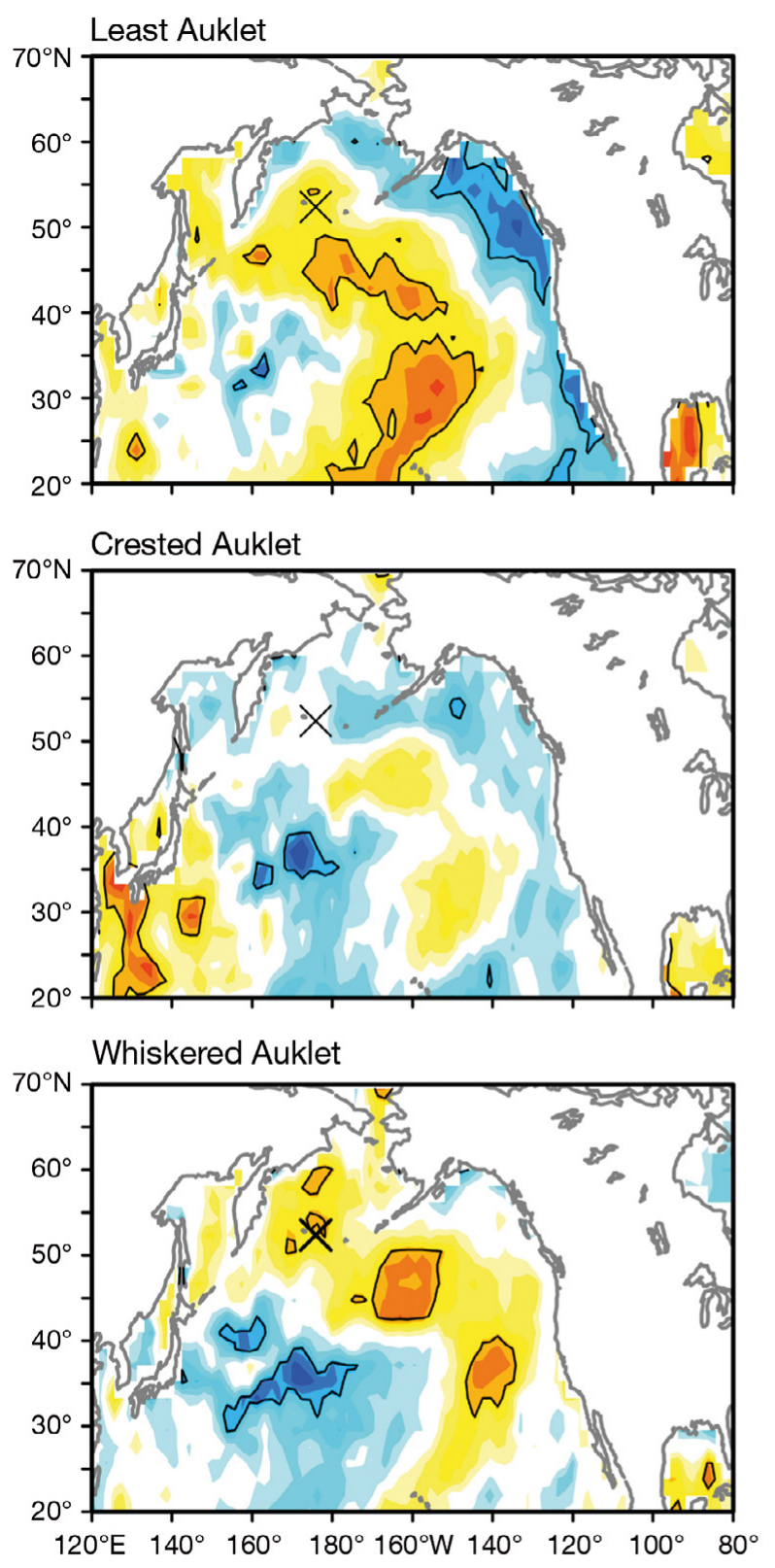

Kasatochi

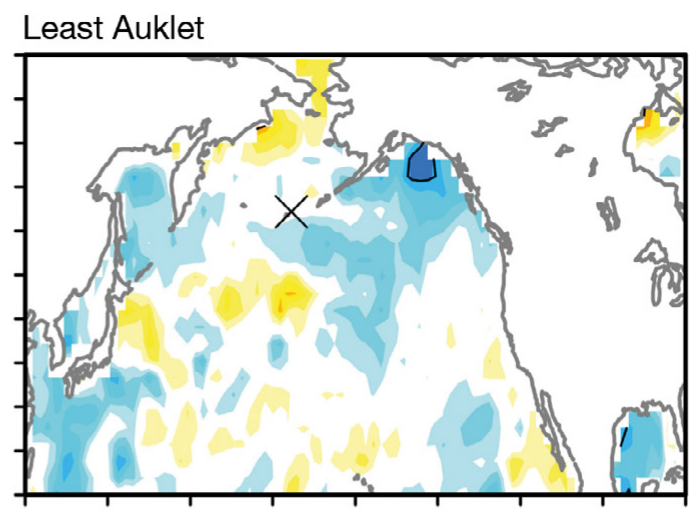

\section{Crested Auklet}

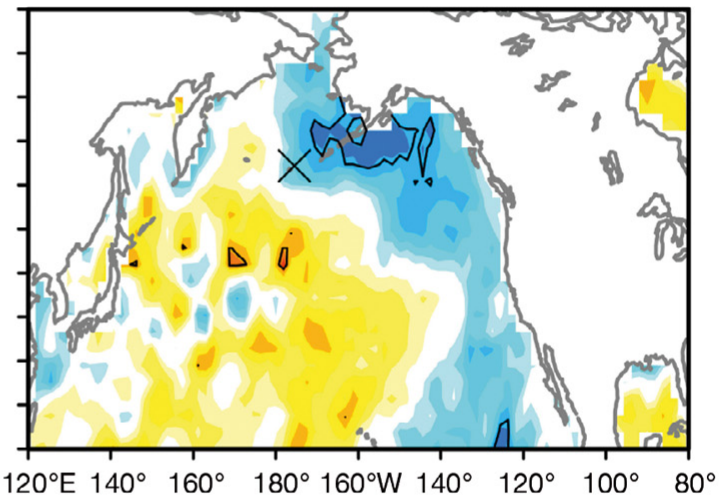

Fig. 3. Aethia pusilla, Aethia pygmaea, and Aethia cristatella. Biogeography of Spearman correlation coefficients between least, crested, and whiskered auklet productivity on Buldir and Kasatochi, and winter sea surface temperature. Contours indicate significant $(p<0.10)$ Spearman correlations, with the assumption that each year's productivity measure was independent

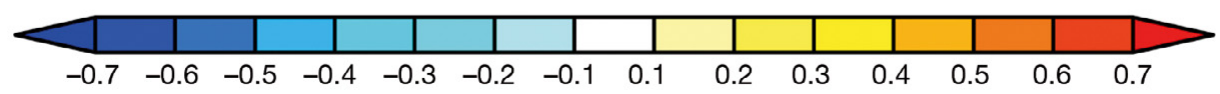

\section{Sea surface temperature December-January-February correlation with auklet productivity}

\section{Factors affecting auklet productivity}

Based on the results from our examination of correlation coefficients and spatial correlation analysis, we included only ALPI and NPGO (winter and spring) along with local breeding-season SST as covariates in the generalized linear models. The best-fitting model for productivity of all auklets from 1990 to 2008 included differences among species and islands, ALPI, and the Island $\times$ ALPI interaction term. No other model had $\Delta$ QAIC $_{\mathrm{C}}<2$, and the top model received $72 \%$ support, 3 times more than the second-best model after adjust- 


\section{Buldir}
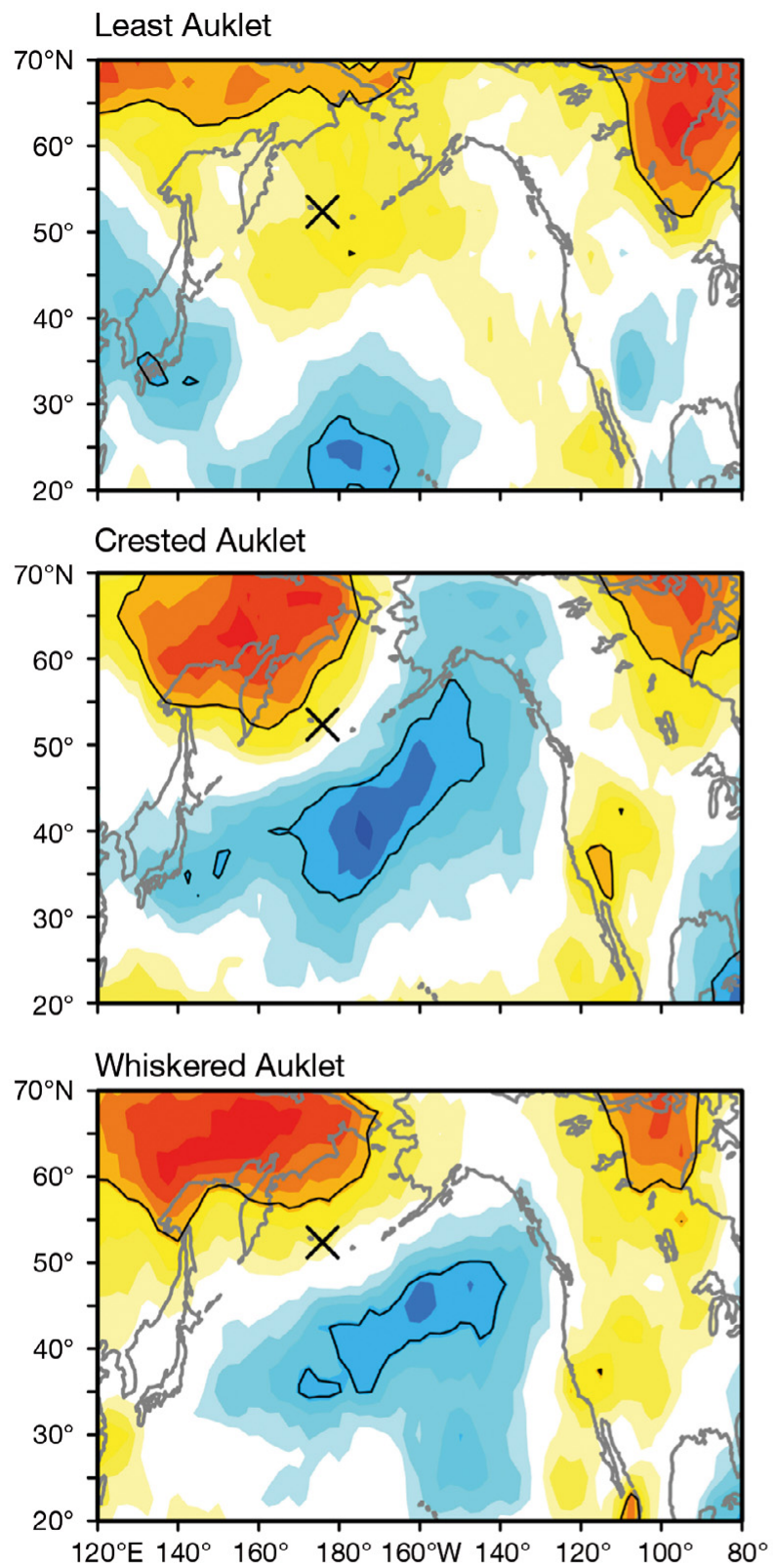

\section{Kasatochi}
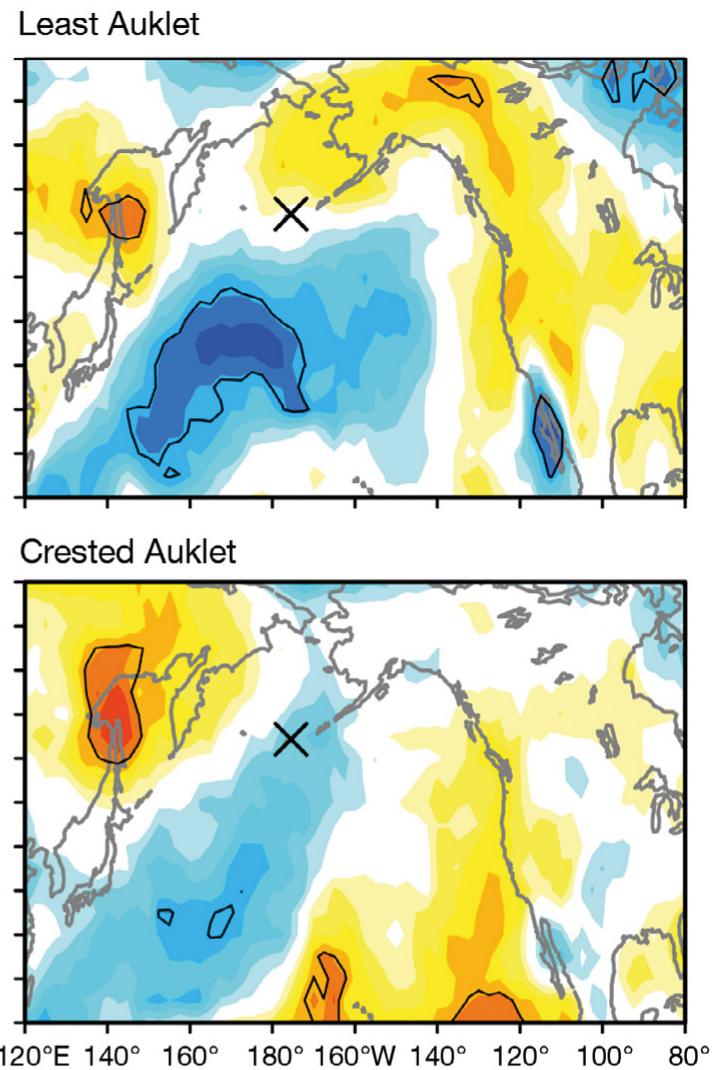

Fig. 4. Aethia pusilla, Aethia pygmaea, and Aethia cristatella. Biogeography of Pearson correlation coefficients between least, crested, and whiskered auklet reproductive success on Buldir and Kasatochi, and spring sea-level pressure. Contours indicate significant $(p<0.10)$ Spearman correlations, with the assumption that each year's productivity measure was independent

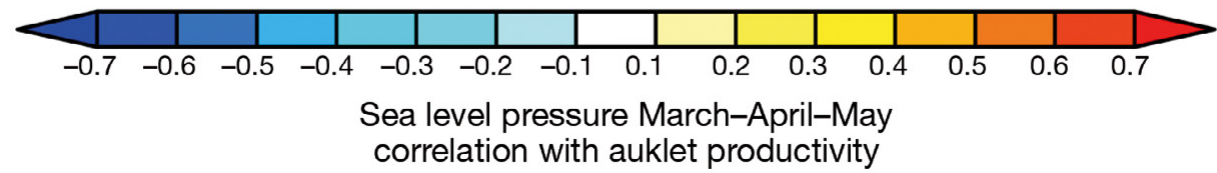

ing for $\hat{\mathrm{c}}=5.62$ (Table 4). Parameter estimates are presented in Table 5.

Using data from only Buldir and Kasatochi, the top 2 models included effects of Species and ALPI, with one model including their interaction. These models were almost equally supported, but were more than 7 times more supported than the third-ranked model after correcting for $\hat{\mathrm{c}}=4.23$ (Table 6 ).

Based on EMMs from the full dataset, Buldir and Kasatochi had similar reproductive success rates during the study, and both were higher than Kiska. Among islands, crested and whiskered auklets had 
Table 4. Summary of the model set for predicting productivity of least, crested, and whiskered auklets on Buldir, Kiska, and Kasatochi, Aleutian Islands, Alaska

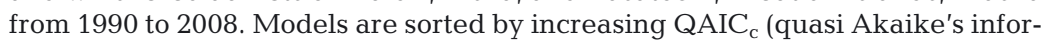
mation criteria corrected for small sample size) value with the most parsimonious model at the top. Akaike weight $\left(\mathrm{w}_{i}\right)$ is the likelihood that a given model of the model set is the best approximation of the data. Model parameters: I: island, S: species, ALPI: Aleutian Low Pressure Index, NPGO: North Pacific Gyre Oscillation (DJF: December to February; MAM: March to May), SST: sea surface temperature. Model corrected for $\hat{\mathrm{c}}=5.62 . \Delta \mathrm{QAIC}_{\mathrm{c}}$ is the difference from the top-ranked model

\begin{tabular}{|lcrrr|}
\hline Model & $\begin{array}{c}\text { No. of } \\
\text { parameters }\end{array}$ & QAIC $_{\mathrm{c}}$ & $\Delta \mathrm{QAIC}_{\mathrm{c}}$ & $\mathrm{w}_{i}$ \\
\hline I + S + ALPI + I × ALPI & 8 & 1818.624 & 0.000 & 0.72 \\
I + S + ALPI + I × ALPI + S × ALPI & 11 & 1820.790 & 2.166 & 0.24 \\
I + S + ALPI & 6 & 1825.154 & 6.529 & 0.03 \\
I + S + ALPI + S × ALPI & 8 & 1826.500 & 7.876 & 0.01 \\
I + S + NPGO-DJF & 7 & 1832.111 & 13.486 & 0.00 \\
I + S + NPGO-MAM & 7 & 1839.563 & 20.939 & 0.00 \\
I + S & 5 & 1844.406 & 25.782 & 0.00 \\
I + S + SST & 6 & 1845.380 & 26.756 & 0.00 \\
I + S + I × S & 8 & 1847.243 & 28.619 & 0.00 \\
S & 3 & 1854.478 & 35.854 & 0.00 \\
I & 3 & 1856.643 & 38.018 & 0.00 \\
Intercept only & 1 & 2496.983 & 678.359 & 0.00 \\
\hline
\end{tabular}

Table 5. Parameter estimates from the top-ranked generalized linear model (Table 7) for productivity of least, crested, and whiskered auklets on Buldir, Kiska, and Kasatochi, Aleutian Islands, from 1990 to 2008

\begin{tabular}{|lccccccc|}
\hline \multirow{2}{*}{ Parameter } & \multirow{2}{*}{$\beta$} & SE & \multicolumn{2}{c}{$95 \%$ CI } & Wald & df & p-value \\
& & & Lower & Upper & $\chi^{2}$ & & \\
\hline Intercept & 0.391 & 0.1009 & 0.193 & 0.588 & 14.975 & 1 & $<0.001$ \\
Crested auklet & 0.203 & 0.0794 & 0.047 & 0.358 & 6.508 & 1 & 0.011 \\
Least auklet & -0.274 & 0.0784 & -0.428 & -0.121 & 12.246 & 1 & $<0.001$ \\
Whiskered auklet & $0^{\mathrm{a}}$ & - & - & - & - & - & - \\
Buldir & 0.200 & 0.0824 & 0.039 & 0.362 & 5.903 & 1 & 0.015 \\
Kasatochi & 0.148 & 0.0849 & -0.018 & 0.315 & 3.049 & 1 & 0.081 \\
Kiska & $0^{\mathrm{a}}$ & - & - & - & - & - & - \\
ALPI & -0.273 & 0.0263 & -0.325 & -0.222 & 108.252 & 1 & $<0.001$ \\
Buldir $\times$ ALPI & 0.168 & 0.0317 & 0.106 & 0.230 & 27.926 & 1 & $<0.001$ \\
Kasatochi $\times$ ALPI & 0.220 & 0.0330 & 0.155 & 0.285 & 44.490 & 1 & $<0.001$ \\
Kiska $\times$ ALPI & $0^{\mathrm{a}}$ & - & - & - & - & - & - \\
a This parameter is set to 0 & because it is redundant & & & \\
\hline
\end{tabular}

Table 6. Summary of the model set explaining productivity of least, crested, and whiskered auklets in the Aleutian Islands from 1990 to 2008 using only data from Buldir and Kasatochi. For model sorting information and abbreviations, see Table 4. Model corrected for $\hat{\mathrm{c}}=4.23$

\begin{tabular}{|lccrc|}
\hline Model & $\begin{array}{c}\text { No. of } \\
\text { parameters }\end{array}$ & QAIC $_{\mathrm{c}}$ & $\Delta$ QAIC $_{\mathrm{c}}$ & $\mathrm{w}_{i}$ \\
\hline S + ALPI + S $\times$ ALPI & 6 & 1942.986 & 0.000 & 0.49 \\
S + ALPI & 4 & 1943.267 & 0.281 & 0.43 \\
S + NPGO-DJF & 4 & 1947.378 & 4.391 & 0.05 \\
S + NPGO-MAM & 4 & 1949.853 & 6.866 & 0.02 \\
S & 3 & 1951.288 & 8.302 & 0.01 \\
S + SST & 4 & 1952.190 & 9.203 & 0.00 \\
I + S + I $\times$ S & 5 & 1953.267 & 10.281 & 0.00 \\
Intercept only & 1 & 1964.425 & 21.439 & 0.00 \\
I & 2 & 1965.426 & 22.440 & 0.00 \\
\hline
\end{tabular}

higher reproductive success than least auklets (Table 7). An increased ALPI was associated with decreased productivity among all species on all islands $(\beta=-0.273 \pm 0.0263$ [SE] (Fig. 5).

\section{DISCUSSION}

Our results indicate that auklet reproductive success varied with largescale climate indices, and that even with a short time series for multiisland comparisons ( $7 \mathrm{yr}$ ), the majority of correlations (9 of 10) were in phase. The combination of only 7 years' data from Kiska and the potentially confounding effect of introduced Norway rats complicates the interpretation, but performing analysis using data from only Buldir and Kasatochi, combined with independent spatial correlation analysis, yielded similar patterns. We note, however, that the oscillation between 'warm' and 'cold' phases of the Pacific Ocean may be masked or accentuated by increasing global temperatures (d'Orgeville \& Peltier 2009), and so our correlations should be treated as minimum estimates.

Interestingly, we found no evidence of linear trends in our reproductive success or phenology data, contrary to that found in piscivorous seabirds in the Pribilof Islands (Byrd et al. 2008) and North Atlantic (Gaston et al. 2005, Moe et al. 2009). It is likely that our relatively short time series overall (19 yr) was insufficient to document potential climate-linked trends in productivity.

Reproductive success tended to be more correlated among species on the same island than for any single species among islands. Least and crested auklets tend to provision their chicks with diets consisting of euphausiids and calanoid copepods (Bédard 1969, Day \& Byrd 1989, Hunt \& Harrison 1990), so the observed pattern suggests that general prey availability differences among breeding sites were more important than species-specific factors. Several studies have now examined 
Table 7. Estimated marginal mean (EMM) productivity for least, crested, and whiskered auklets on Buldir, Kiska, and Kasatochi in the Aleutian Islands, from 1990 to 2008 as derived from the top-ranked generalized linear model. Differences are considered significant when confidence intervals (CI) do not overlap

\begin{tabular}{|lcc|}
\hline Parameter & EMM & $95 \%$ CI \\
\hline Least auklet & 0.45 & $0.43-0.47$ \\
Crested auklet & 0.60 & $0.56-0.64$ \\
Whiskered auklet & 0.62 & $0.59-0.65$ \\
Buldir & 0.62 & $0.60-0.63$ \\
Kiska & 0.35 & $0.29-0.41$ \\
Kasatochi & 0.61 & $0.59-0.63$ \\
\hline
\end{tabular}

the relationships between climate indices or local oceanographic conditions and timing of breeding in the Alcidae and found trends for earlier breeding (Gaston et al. 2005, Moe et al. 2009), later breeding (Byrd et al. 2008, Wanless et al. 2009), or no trend over time (Abraham \& Sydeman 2004, Durant et al. 2004, this study). While snow cover, and consequently air temperature, may delay auklet nesting at northern colonies (Sealy 1975, Moe et al. 2009), breeding colonies in the Aleutian Islands are snow-free when auklets initiate nesting in late May or early June (data not shown).

\section{Influence of climate on reproductive performance}

Overall, a higher ALPI, which corresponded with a stronger, more intense Aleutian low-pressure system, was associated with decreased productivity in least, whiskered, and crested auklets across their range in the Aleutian Islands, Alaska, although the magnitude of this relationship was variable among species and islands. A stronger Aleutian low is supposed to correspond with a larger spring algal bloom in the Bering Sea (Iida \& Saitoh 2007) but also possibly with a decrease in zooplankton biomass due to cold temperature limitation (Walsh \& McRoy 1986, Huntley \& Lopez 1992, Pinchuk et al. 2008). In the eastern Bering Sea, warmer SST (and positive values of PDO) were predicted to result in a decrease in zooplankton biomass in surface waters during the auklets' breeding season (Coyle et al. 2008, Jin et al. 2009), likely caused by the copepods' early descent in the water column to undergo diapause (Miller et al. 1984, Miller \& Nielson 1988). In the northern Bering Sea, auklets are less selective in the prey species they choose when zooplankton abundance is low (Springer \& Roseneau 1985, Hunt \& Harrison 1990, Russell et al. 1999). Under these conditions, prey species that are not typically exploited by auklets because of their lower energy content (e.g. Calanus marshallae) are
Buldir
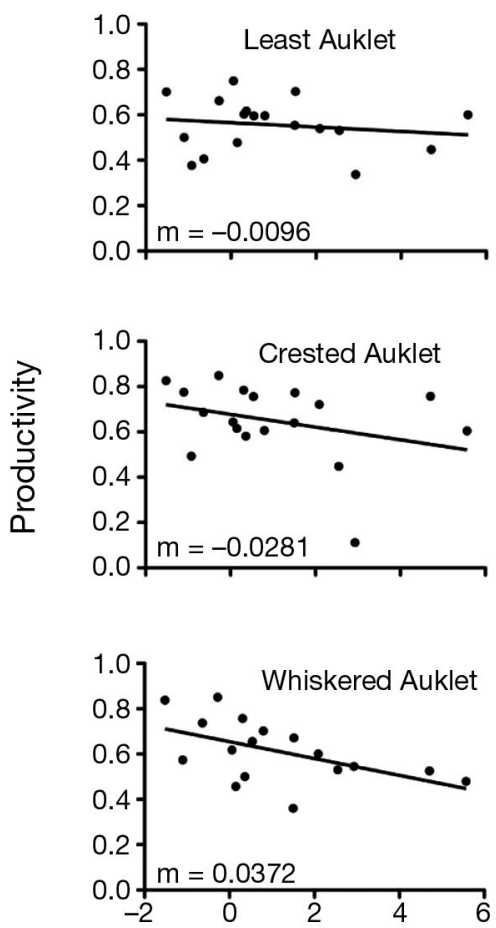

Aleutian Low Pressure Index
Kiska
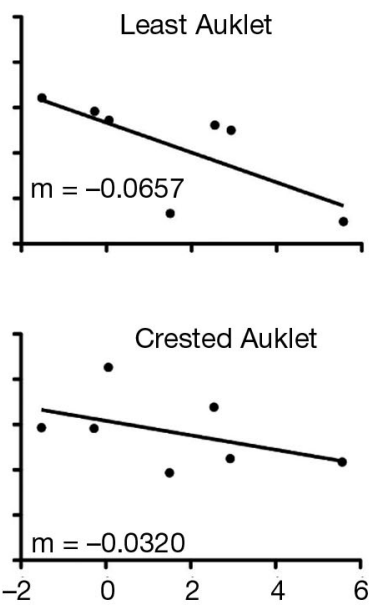

Aleutian Low Pressure Index
Kasatochi
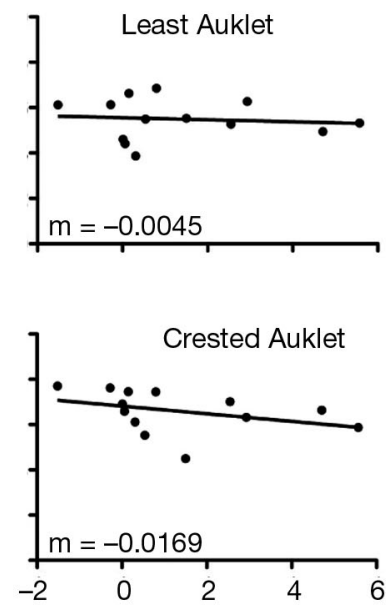

Fig. 5. Aethia pusilla, Aethia pygmaea, and Aethia cristatella. Productivity (number of fledglings per number of eggs laid) of least, crested and whiskered auklets on Buldir, Kiska, and Kasatochi from 1990 to 2008 showing the generally negative relationship with the Aleutian Low Pressure Index 
more prevalent in adult and chick diet. The same could be true in the Aleutian Islands during a stronger Aleutian low, leading to a decrease in productivity. Survival of auklet chicks is related to the quality of prey items delivered by their parents (Gall et al. 2006). In the northern California Current System, Cassin's auklets have low reproductive success in warm years when biomass of their main prey species Neocalanus cristatus peaked early and was consequently not abundant in chicks' diet (Sydeman et al. 2006). We do not believe that such a mismatch occurred with Aethia auklets in the Aleutian Islands, as chick diet composition has been relatively constant over our study period (data not shown).

Aside from indirect effects of ocean climate via impacts on productivity, direct effects are also possible and non-mutually exclusive to indirect effects (Jones et al. 2007). Heavy rainfall during early chick rearing can flood nesting crevices, resulting in chick death (Bond A.L., Jones I. L. pers. obs). The relative importance of such local, atypical effects compared to prey availability is unknown.

Another direct effect of stormy weather could operate via increased wave action, which is thought to decrease availability of zooplankton to predators (Wroblewski \& Richman 1987). Unfortunately, land-based field observational studies (such as ours) alone do not provide direct information on plankton availability, and are therefore inadequate to confirm the relative roles of direct and indirect effects of ocean climate on auklet breeding success.

\section{ALPI and NPGO}

Conveniently, our 3 study islands lie nearly at the centre of the geographic area used for ALPI calculations. ALPI is also measured over the period December to March, and other studies have found significant relationships between seabird reproductive performance and winter climate (Abraham \& Sydeman 2004, Durant et al. 2006, Byrd et al. 2008, Sandvik et al. 2008), presumably through climate-mediated controls on prey development, abundance, and distribution (Kitaysky \& Golubova 2000, Frederiksen et al. 2006, Byrd et al. 2008). We previously found that adult survival in whiskered auklets covaried with ALPI as well, through either direct (negative effects of a stormy North Pacific) or indirect effects (i.e. bottom-up control of food supplies) (Jones et al. 2007). This contrasts partly with recent findings that reproductive success in Cassin's auklet Ptychoramphus aleuticus is driven by local factors rather than large-scale climatic variables (Wolf et al. 2009). Cassin's auklet chicks are fed only at night by their nocturnal parents, grow slower, and take much longer to fledge than Aethia auklets (Ydenberg 1989), meaning that there is a larger timeframe over which nocturnal species' reproductive success may be affected by climatic variation. Cassin's auklets breed from southern California to the Aleutian Islands, so that large-scale climate variation is likely to be inherently more variable over their range than that of Aethia auklets in our study. Pacific-wide climate patterns affect the coasts of California, British Columbia, and Alaska differently and span several oceanic domains (California Current, North Pacific Current, Alaska Coastal Current). Our study of auklets in the Aleutian Islands spans one oceanic domain where large-scale climate effects would likely be more consistent than those experienced by Cassin's auklets in the study by Wolf et al. (2009).

The NPGO is an index of sea surface height and temperature anomalies over 110 to $180^{\circ} \mathrm{W}$ and 25 to $62^{\circ} \mathrm{N}$ (Di Lorenzo et al. 2008) and tends to explain more of the SST anomaly than the PDO (Bond et al. 2003). It is controlled largely by basin-wide variations in upwelling and advection in the ocean and therefore influences nutrient abundance and salinity directly (Di Lorenzo et al. 2009), which in turn affects the abundance of plankton (Di Lorenzo et al. 2008). In all cases where the relationship between Aleutian auklet productivity and either winter or spring NPGO was significant, the relationship was negative, such that a higher NPGO index corresponded with lower reproductive success. A high NPGO is associated with a stronger Aleutian Gyre in the Gulf of Alaska and a stronger North Pacific Current, the main warmwater current that runs west to east along the south of the Aleutian chain at about 40 to $50^{\circ} \mathrm{N}$. Furthermore, the NPGO mode has been strengthening since about 1993 (Bond et al. 2003, Di Lorenzo et al. 2008) and may be the result of anthropogenic climate change (Di Lorenzo et al. 2008). Furthermore, the NPGO and the Aleutian low-pressure system are linked to ENSO dynamics. There is an atmospheric teleconnection between the Aleutian low and ENSO, and the North Pacific Oscillation (which is related to the NPGO) leads ENSO by approximately 8 to 12 mo (Di Lorenzo et al. unpubl. data). Biologically, this means that there should be concern about the Aleutian Islands' population of auklets, as both increased ALPI and NPGO are related to decreased reproductive success, likely through a bottom-up mechanism of limiting prey availability during either the prebreeding period (Schroeder et al. 2009) or during chick rearing (Gall et al. 2006). Combined with vegetative succession (Roby \& Brink 1986) and the detrimental effects of rats on Kiska (Major et al. 2006), the effects of oceanography or climate may be masked or dampened by colony effects. 


\section{Geospatial mapping of climate and reproductive success}

The strongest geospatial correlations provided evidence based on winter SST correlations that reproductive success of least auklets on Buldir might be related to the PDO (Fig. 3). Similarly, the correlation map for whiskered auklet reproductive success on Buldir, and winter and spring SST (Fig. 3) resembled the Victoria mode of SST anomalies (Bond et al. 2003). The Victoria mode is the atmospheric expression of the NPGO in the North Pacific Oscillation, an atmospheric SLP pattern. We again found only weak correlations, possibly because of our short time scale.

The negative relationship between auklet productivity and winter SST in the Gulf of Alaska further suggests a bottom-up mechanism. Warmer SST is related to earlier timing of life history events by copepods (Mackas et al. 2007), including diapause, which may render the copepods unavailable to auklets (Goldblatt et al. 1999, Richardson 2008). Data from continuous plankton recorders in the North Pacific showed a marked decrease in copepod abundance in winter (December to March), although smaller numbers may remain accessible to seabird predators (Fort et al. 2010).

Critical to an understanding of geospatial patterns of demography-oceanography relationships in seabirds is an understanding of the birds' spatial distribution during the time of interest, which in our case is winter and spring. Knowledge of the non-breeding distributions of Aethia auklets, especially from the ice-free Aleutians, is poor. Whiskered auklets are believed to be non-migratory, spending winters in the vicinity of the breeding colony (Stejneger 1885, Konyukhov \& Zubakin 1994, Zubakin \& Konyukhov 1994, Gibson \& Byrd 2007). Crested auklets winter in the eastern Aleutians, particularly in productive upwelling areas such as Unimak Pass (Renner et al. 2008, Sydeman et al. 2010). Least auklets are more abundant in the western Pacific during the winter and spring (Vyatkin 1981, Sydeman et al. 2010), while some winter in the Sea of Japan off the coast of Primoye, Russia (Shuntov 1965, Velizhanin 1977, Kondratyev et al. 2000), although the extent of mixing between Russian and North American populations is unknown. Nevertheless, large-scale climate patterns would be expected to influence the species differently during the winter, but as the relationships between ALPI and productivity among all species on all islands was similar, the differing effects may manifest themselves in a similar way.

\section{Other factors affecting reproductive success}

In general, all species' reproductive success was negatively related to the ALPI across all islands, but local factors must also have been important. These factors included variable abundance and predation by avian predators such as the glaucous-winged gull Larus glaucescens, the peregrine falcon Falco peregrinus, and the bald eagle Haliaeetus leucocephalus. In addition, auklet reproductive success was affected by rainstorms during peak hatching periods when chicks were vulnerable to chilling, and earthquakes collapsing auklet breeding crevices. An extreme example of local effects was the August 7, 2008, eruption on Kasatochi, which buried the entire auklet colony site under thousands of tons of hot volcanic ash, entombing late auklet chicks and any accompanying adults (Williams et al. 2010). Another example is introduced Norway rat population that has been present on Kiska since the 1940s (Murie 1959). The rats were implicated in causing severe reproductive failure in least auklets on Kiska in 2001 and 2002 (Major et al. 2006). Auklets form a considerable portion of the rats' diet, and caches of dead birds were found annually, being especially large in the years of breeding failure (Major et al. 2007).

\section{CONCLUSIONS}

Our results indicated that ocean climate and associated effects on ocean productivity and frequency and intensity of storms influence variation in Aleutian Aethia auklet reproductive performance. Colony-specific effects, such as variation in the abundance and behaviour of naturally occurring and introduced predators, vegetative succession, and even seismic and volcanic activity must also be considered.

Acknowledgements. We thank the many field workers who collected this abundance of data over 20 yr. Especially noteworthy are the multi-year efforts of several people indicated with an asterisk ( $\left.{ }^{*}\right)$ : E. Andersen* ${ }^{*}$ M. Barrett, D. Barton, G. Beyersdorf*, C. Brake, K. Brenneman, R. Buchheit, D. Clutter, J. Daniels, E. Drew, B. Drummond*, A. Durand, J. Dussureault* , C. Eggleston*, K. Elkin, J. Fischer*, J. C. Ford, S. Freeman*, C. Gray, M. Grinnell, J. M. Hipfner*, S. Hootman, N. Jones, T. Joyce*, P. Kappes, B. Keller, S. Kissler, H. Knechtel $^{*}$, N. Konyukhov, S. Lantz, A. Larned, K. Lindquist, G. Loh, S. Lorenz, J. Marais, M. McClintock, L. Meehan, J. Mueller, M. Murphy*, R. Orben, M. Ortwerth, A. Palmer, L. Parker, K. Payne, J. Petersen, D. Rehder, H. Renner*, A. Ritchie, N. Rojek*, K. Russell, P. Ryan, G. Samson, S. Sapora, C. Schlawe, N. Seferovic, K. Shea, E. Sommer, L. Spitler*, A. Stoertz, A. Stover, S. Syria*, G. Thomson, C. VanStratt, R. Walder, and H. Walsh. The MV 'Tiĝlax' and her crews provided logistical support. The North Pacific Research Board (grant no. 638), Natural Sciences and Engineering Research Council of Canada, Alaska Maritime National Wildlife Refuge, and Northern Scientific Training Program of Indian and Northern Affairs Canada provided financial support for this research. This is publication no. 283 of the North Pacific Research Board. A. R. Breton, A. P. Lusignan, and 
G. J. Robertson gave statistical advice, G. W. Humphries assisted with the remotely sensed data, and T. W. Chapman, E. H. Miller, G. J. Robertson, M. Frederiksen, R. P. Wilson, and 3 anonymous reviewers provided improvements on previous drafts of this manuscript.

\section{LITERATURE CITED}

Abraham CL, Sydeman WJ (2004) Ocean climate, euphausiids and auklet nesting: inter-annual trends and variation in phenology, diet and growth of a planktivorous seabird, Ptychoramphus aleuticus. Mar Ecol Prog Ser 274:235-250

> Beamish RJ, Bouillon DR (1993) Pacific salmon production trends in relation to climate. Can J Fish Aquat Sci 50: 1002-1016

Beamish RJ, Neville CEM, Cass AJ (1997) Production of Fraser River sockeye salmon (Oncorhynchus nerka) in relation to decadal-scale changes in the climate and the ocean. Can J Fish Aquat Sci 54:543-554

Bédard J (1969) Feeding of Least, Crested and Parakeet Auklets around St. Lawrence Island, Alaska. Can J Zool 47: 1025-1050

Benjamini Y, Hochberg Y (1995) Controlling the false discovery rate: a practical and powerful approach to multiple testing. J R Stat Soc, B 57:289-300

Biondi F, Gershunov A, Cayan DR (2001) North Pacific decadal climate variability since 1661. J Clim 14:5-10

Bond NA, Overland JE, Spillane M, Stabeno P (2003) Recent shifts in the state of the North Pacific. Geophys Res Lett 30:2183-2186

Burnham KP, Anderson DR (2002) Model selection and multimodel inference: a practical information-theoretic approach. Springer, New York, NY

Byrd GV, Williams JC (1993) Whiskered Auklet (Aethia pygmaea). In: Poole A (ed) The birds of North America online. Cornell Lab of Ornithology, Ithaca, NY, available at http://bna.birds.cornell.edu/bna/species/076

> Byrd GV, Sydeman WJ, Renner HM, Minobe S (2008) Responses of piscivorous seabirds at the Pribilof Islands to ocean climate. Deep-Sea Res II 55:1856-1867

Chavez FP, Strutton PG, Friedrich GE, Feely RA, Feldman GC, Foley DG, McPhaden MJ (1999) Biological and chemical response of the equatorial Pacific Ocean to the 199798 El Niño. Science 286:2126-2131

> Coyle KO, Pinchuk AI, Eisner LB, Napp JM (2008) Zooplankton species composition, abundance and biomass on the eastern Bering Sea shelf during summer: the potential role of water-column stability and nutrients in structuring the zooplankton community. Deep-Sea Res II 55:1775-1791

> Day RH, Byrd GV (1989) Food habits of the whiskered auklet at Buldir Island, Alaska. Condor 91:65-72

- Di Lorenzo E, Schneider N, Cobb KM, Franks PJS and others (2008) North Pacific Gyre Oscillation links ocean climate and ecosystem change. Geophys Res Lett 35:L08607

> Di Lorenzo E, Fiechter J, Schneider N, Bracco A and others (2009) Nutrient and salinity decadal variations in the central and eastern North Pacific. Geophys Res Lett 36: L14601

> d'Orgeville M, Peltier WR (2009) Implications of both statistical equilibrium and global warming simulations with CCSM3. Part I: on the decadal variability in the North Pacific Basin. J Clim 22:5277-5297

> Durant JM, Anker-Nilssen T, Hjermann DØ, Stenseth NC (2004) Regime shifts in the breeding of an Atlantic puffin population. Ecol Lett 7:388-394
Durant JM, Anker-Nilssen T, Stenseth NC (2006) Ocean climate prior to breeding affects the duration of the nesting period in the Atlantic puffin. Biol Lett 2:628-631

$>$ Durant JM, Hjermann DØ, Frederiksen M, Charraissin JB and others (2009) Pros and cons of using seabirds as ecological indicators. Clim Res 39:115-129

> Field SA, Tyre AJ, Jonzén N, Rhodes JR, Possingham HP (2004) Minimizing the cost of environmental management decisions by optimizing statistical thresholds. Ecol Lett 7:669-674

Flint MV, Golovkin AN (2002) How do planktivorous least auklets (Aethia pusilla) use foraging habitats around breeding colonies? Adaptation to mesoscale distribution of zooplankton. Oceanology (Mosc) 42:S114-S121

Fort J, Cherel Y, Harding AMA, Egevang C, Steen H, Kuntz1 G, Porter WP, Grémillet D (2010) The feeding ecology of Little Auks raises questions about winter zooplankton stocks in North Atlantic surface waters. Biol Lett 6: 682-684

Fraser GS, Jones IL, Williams JC, Hunter FM, Scharf L, Byrd GV (1999) Breeding biology of Crested Auklets at Buldir and Kasatochi Islands, Alaska. Auk 116:690-701

Frederiksen M, Edwards M, Richardson AJ, Halliday NC, Wanless S (2006) From plankton to top predators: bottomup control of a marine food web across four trophic levels. J Anim Ecol 75:1259-1268

Gall AE, Roby DD, Irons DB, Rose IC (2006) Differential response in chick survival to diet in Least and Crested Auklets. Mar Ecol Prog Ser 308:279-291

> García LV (2004) Escaping the Bonferroni iron claw in ecological studies. Oikos 105:657-663

- Gaston AJ, Gilchrist HG, Hipfner JM (2005) Climate change, ice conditions and reproduction in an Arctic nesting marine bird: Brunnich's guillemot (Uria lomvia L.). J Anim Ecol 74:832-841

Gibson DD, Byrd GV (2007) Birds of the Aleutian Islands, Alaska. The Nuttal Ornithological Club \& The American Ornithologists' Union, Cambridge, MA \& Washington, DC

> Gjerdrum C, Vallée AMJ, St. Clair CC, Bertram DF, Ryder JL, Blackburn GS (2003) Tufted Puffin reproduction reveals ocean climate variability. Proc Natl Acad Sci USA 100: 9377-9382

Goldblatt RH, Mackas DL, Lewis AG (1999) Mesozooplankton community characteristics in the NE subarctic Pacific. Deep-Sea Res II 46:2619-2644

> Grosbois V, Giminez O, Gaillard JM, Pradel R, Barbraud C, Clobert J, Møller AP, Weimerskirch H (2008) Assessing the impact of climate variation on survival in vertebrate populations. Biol Rev Camb Philos Soc 83:357-399

Hare SR, Mantua NJ (2000) Empirical evidence for North Pacific regime shifts in 1977 and 1989. Prog Oceanogr 47: 103-145

Harris MP, Anker-Nilssen T, McCleery RH, Erikstad KE, Shaw DN, Grosbois V (2005) Effect of wintering area and climate on the survival of adult Atlantic Puffins Fratercula arctica in the eastern Atlantic. Mar Ecol Prog Ser 297: 283-296

> Hunt BG, Elliott TI (2004) Interaction of climatic variability with climatic change. Atmos-ocean 42:145-172

> Hunt GL Jr, Harrison NM (1990) Foraging habitat and prey taken by Least Auklets at King Island, Alaska. Mar Ecol Prog Ser 65:141-150

Hunt GL Jr, Stabeno P, Walters G, Sinclair E, Brodeur RD, Napp JM, Bond NA (2002) Climate change and control in the southeastern Bering Sea pelagic ecosystem. Deep-Sea Res II 49:5821-5823

> Hunt GL Jr, Stabeno PJ, Strom S, Napp JM (2008) Patterns of spatial and temporal variation in the marine ecosystem of 
the southeastern Bering Sea, with special reference to the Pribilof Domain. Deep-Sea Res II 55:1919-1944

Hunter FM, Jones IL, Williams JC, Byrd GV (2002) Breeding biology of the Whiskered Auklet (Aethia pygmaea) at Buldir Island, Alaska. Auk 119:1036-1051

Huntley ME, Lopez MDG (1992) Temperature-dependent production of marine copepods: a global synthesis. Am Nat 140:201-242

Iida T, Saitoh SI (2007) Temporal and spatial variability of chlorophyll concentrations in the Bering Sea using empirical orthogonal function (EOF) analysis of remote sensing. Deep-Sea Res II 54:2657-2671

Jenouvrier S, Thibault JC, Viallefont A, Vidal P and others (2009) Global climate patterns explain range-wide synchronicity in survival of a migratory seabird. Glob Change Biol 15:268-279

Jin M, Deal C, Wang J, McRoy CP (2009) Response of lower trophic level production to long-term climate change in the southeastern Bering Sea. J Geophys Res 114:C04010

Jones IL (1993a) Crested Auklet (Aethia cristatella). In: Poole A (ed) The birds of North America online. Cornell Lab of Ornithology, Ithaca, NY, available at http://bna.birds. cornell.edu/bna/species/070

Jones IL (1993b) Least Auklet (Aethia pusilla). In: Poole A (ed) The birds of North America online. Cornell Lab of Ornithology, Ithaca, NY, available at http://bna.birds. cornell.edu/bna/species/069

Jones IL, Hunter FM, Robertson GJ (2002) Annual adult survival of Least Auklets (Aves, Alcidae) varies with largescale climatic conditions of the North Pacific Ocean. Oecologia 133:38-44

> Jones IL, Hunter FM, Robertson GJ, Williams JC, Byrd GV (2007) Covariation among demographic and climate parameters in Whiskered Auklets Aethia pygmaea. J Avian Biol 38:450-461

Kalnay E, Kanamitsu M, Kistler R, Collins W and others (1996) The NCEP/NCAR 40-year reanalysis project. Bull Am Meteorol Soc 77:437-471

Kitaysky AS, Golubova EG (2000) Climate change causes contrasting trends in reproductive performance of planktivorous and piscivorous alcids. J Anim Ecol 69:248-262

Kondratyev AY, Litvenenko NM, Shibaev YV, Vyatkin PS, Kondratyeva LF (2000) The breeding seabirds of the Russian Far East. In: Kondratyev AY, Litvenenko NM, Kaiser GW (eds) Seabirds of the Russian Far East. Can Wildl Serv Spec Pub, Ottawa, ON, p 37-81

Konyukhov NB, Zubakin VA (1994) Paradoxes of the Whiskered Auklet (Aethia pygmaea) II. Return of juveniles to a colony. Bering Seabird Bull 2:60-63

Lavers JL, Jones IL, Diamond AW, Robertson GJ (2008) Annual survival of North American Razorbills (Alca torda) varies with ocean climate indices. Can J Zool 86:51-61

Lebreton JD, Burnham KP, Clobert J, Anderson DR (1992) Modeling survival and testing biological hypotheses using marked animals: a unified approach and case studies. Ecol Monogr 62:67-118

Lehodey P (2004) Climate and fisheries: an insight from the Central Pacific Ocean. In: Stenseth NC, Otterson G (eds) Marine ecosystems and climate variation. Oxford University Press, Oxford, p 137-146

Mackas DL, Batten S, Trudel M (2007) Effects on zooplankton of a warmer ocean: recent evidence from the Northeast Pacific. Prog Oceanogr 75:223-252

> Major HL, Jones IL, Byrd GV, Williams JC (2006) Assessing the effects of introduced Norway rats (Rattus norvegicus) on survival and productivity of Least Auklets (Aethia pusilla). Auk 123:681-694
Major HL, Jones IL, Charette MR, Diamond AW (2007) Variations in the diet of introduced Norway rats (Rattus norvegicus) inferred using stable isotope analysis. J Zool (Lond) 271:463-468

- Mantua NJ, Hare SR (2002) The Pacific Decadal Oscillation. J Oceanogr 58:35-44

> Mantua NJ, Hare SR, Zhang Y, Wallace JM, Francis RC (1997) A Pacific interdecadal climate oscillation with impacts on salmon production. Bull Am Meteorol Soc 78:1069-1079

- Miller CB, Nielson D (1988) Development and growth of large, calanid copepods in the ocean subarctic Pacific, May 1984. Prog Oceanogr 20:275-292

Miller CB, Frost BW, Batchelder HP, Clemons MJ, Conway RE (1984) Life histories of large, grazing copepods in a subarctic ocean gyre: Neocalanus plumchrus, Neocalanus cristatus, and Eucalanus bungii in the Northeast Pacific. Prog Oceanogr 13:201-243

Moe B, Stempniewicz L, Jakubas D, Angelier F and others (2009) Climate change and phenological responses of two seabird species breeding in the high-Arctic. Mar Ecol Prog Ser 393:235-246

> Møller AP, Flensted-Jensen E, Mardal W (2006) Rapidly advancing laying date in a seabird and the changing advantage of early reproduction. J Anim Ecol 75:657-665

> Mueter FJ, Boldt JL, Megrey BA, Peterman RM (2007) Recruitment and survival of Northeast Pacific Ocean fish stocks: temporal trends, covariation, and regime shifts. Can J Fish Aquat Sci 64:911-927

> Murie OJ (1959) Fauna of the Aleutian Islands and Alaska Peninsula. N Am Fauna 61:1-364

Obst BS, Russell RW, Hunt GL Jr, Eppley ZA, Harrison NM (1995) Foraging radii and energetics of Least Auklets (Aethia pusilla) breeding on three Bering Sea islands. Physiol Zool 68:647-672

> Overland JE, Miletta J, Bond NA (1999) Decadal variability of the Aleutian low and its relation to high-latitude circulation. J Clim 12:1542-1548

> Pinchuk AI, Coyle KO, Hopcroft RR (2008) Climate-related variability in abundance and reproduction of euphausiids in the northern Gulf of Alaska in 1998-2003. Prog Oceanogr 77:203-216

Renner M, Hunt GL Jr, Piatt JF, Byrd GV (2008) Seasonal and distributional patterns of seabirds along the Aleutian archipelago. Mar Ecol Prog Ser 357:301-311

> Richardson AJ (2008) In hot water: zooplankton and climate change. ICES J Mar Sci 65:279-295

Roby DD, Brink KL (1986) Decline of breeding Least Aukelts on St. George Island, Alaska. J Field Ornithol 57:57-59

> Rodionov SN, Overland JE, Bond NA (2005) Spatial and temporal variability of the Aleutian climate. Fish Oceanogr 14:3-21

Russell RW, Harrison NM, Hunt GL Jr (1999) Foraging at a front: hydrography, zooplankton, and avian planktivory in the northern Bering Sea. Mar Ecol Prog Ser 182:77-93

Sandvik H, Coulson T, Sæther BE (2008) A latitudinal gradient in climate effects on seabird demography: results from interspecific analyses. Glob Change Biol 14:703-713

Schroeder ID, Sydeman WJ, Sarkar N, Thompson SA, Bograd SJ, Schwing FB (2009) Winter pre-conditioning of seabird phenology in the California Current. Mar Ecol Prog Ser 393:211-223

Sealy SG (1975) Influence of snow on egg-laying in auklets. Auk 92:528-538

Shuntov VP (1965) Сезонные аспекты в распределении морских птиц в открытых водах Японского Моря (Seasonal aspects in the distribution of marine birds in the open waters of the Japan Sea). Zool Zh 44:411-422 (in Russian with English abstract) 
Springer AM, Roseneau DG (1985) Copepod-based food webs: auklets and oceanography in the Bering Sea. Mar Ecol Prog Ser 21:229-237 (in Russian with English abstract)

Stejneger L (1885) Results of ornithological explorations in the Commander Islands and in Kamtschatka. Bull US Nat Mus No. 29, Government Printing Office, Washington, DC

Sydeman WJ, Bradley RW, Warzybok P, Abraham CL and others (2006) Planktivorous auklet Ptychoramphus aleuticus responses to ocean climate, 2005: unusual atmospheric blocking? Geophys Res Lett 33:L22S09

Sydeman WJ, Thompson SA, Santora JA, Henry MF, Morgan KH, Batten SD (2010) Macro-ecology of plankton-seabird associations in the North Pacific Ocean. J Plankton Res 32:1697-1713

Szép T, Møller AP (2005) Using remote sensing data to identify migration and wintering areas, and to analyze effects of environmental conditions on migratory birds. In: Greenberg R, Marra PP (eds) Birds of two worlds. Johns Hopkins Press, Baltimore, MD, p 390-400

Thayer JA, Bertram DF, Hatch SA, Hipfner JM, Slater L, Sydeman WJ, Watanuki Y (2008) Forage fish of the Pacific Rim as revealed by diet of a piscivorous seabird: synchrony and relationships with sea surface temperature. Can J Fish Aquat Sci 65:1610-1622

Trenberth KE, Hurrell JW (1994) Decadal atmosphere-ocean variations in the Pacific. Clim Dyn 9:303-319

Velizhanin AG (1977) Новые сведения о морских птицах дальнего востока (New data on sea birds in the Far East). Zool Zh 56:1077-1084 (in Russian with English abstract)

Vyatkin PS (1981) Новые сведения о распространии морских птиц на побережьях Камчатки (New data on the distribution of

Editorial responsibility: Rory Wilson,

Swansea, UK sea birds on the shores of Kamchatka). Byull Mosk O-va Ispyt Prir Otd Biol 86:14-18 (in Russian with English abstract)

- Walsh JJ, McRoy CP (1986) Ecosystem analysis in the southeastern Bering Sea. Cont Shelf Res 5:259-288

Wanless S, Frederiksen M, Walton J, Harris MP (2009) Longterm changes in breeding phenology at two seabird colonies in the western North Sea. Ibis 151:274-285

- Watanuki Y, Ito M, Deguchi T, Minobe S (2009) Climateforced seasonal mismatch between the hatching of Rhinoceros Auklets and the availability of anchovy. Mar Ecol Prog Ser 393:259-271

Williams JC, Drummond BA, Buxton RT (2010) Initial effects of the August 2008 volcanic eruption on breeding birds and marine mammals at Kasatochi Island, Alaska. Arct Antarct Alp Res 42:306-314

Wolf SG, Sydeman WJ, Hipfner JM, Abraham CL, Tershey BR, Croll DA (2009) Range-wide reproductive consequences of ocean climate variability for the seabird Cassin's Auklet. Ecology 90:742-753

- Wroblewski JS, Richman JG (1987) The non-linear response of plankton to wind mixing events - implications for survival of larval northern anchovy. J Plankton Res 9: 103-123

Ydenberg RC (1989) Growth-mortality trade-offs and the evolution of juvenile life histories in the Alcidae. Ecology 70:1494-1506

Zubakin VA, Konyukhov NB (1994) Paradoxes of the Whiskered Auklet (Aethia pygmaea) I. Return of adults of colony after the breeding season. Bering Seabird Bull 2:57-59

Submitted: March 10, 2010; Accepted: December 3, 2010 Proofs received from author(s): February 10, 2011 